\title{
Direct Detection of Black Carbon in Soils by Py-GC/MS, Carbon-13 NMR Spectroscopy and Thermogravimetric Techniques
}

\author{
J. M. De la Rosa* \\ IRNAS-CSIC \\ Reina Mercedes Av. 10 \\ Seville 41012 \\ Spain
}

\section{H. Knicker}

Lehrstuhl für Bodenkunde

Technische Universitat Muchen

D-85350 Freising-Weihenstphan

Germany

\section{E. López-Capel}

D. A. C. Manning

Manning, School of Civil Eng. and Geosciences

University of Newcastle

Newcastle upon Tyne

NE1 7RU

UK

\section{J. A. González-Perez \\ F. J. González-Vila \\ IRNAS-CSIC \\ Reina Mercedes Av. 20 \\ Seville 41012 \\ Spain}

\begin{abstract}
The amount and compositional characteristics of black carbon in soils (mollisol and vertisol), charred biomass (laboratory produced; rice, chestnut), and soils (southern Spain) affected by forest fire have been determined using a combination of thermogravimetry (TG), TG coupled with isotope ratio mass spectrometry (IRMS), solid state ${ }^{13} \mathrm{C}$ nuclear magnetic resonance (NMR) spectroscopy, and pyrolysis-gas chromatography/mass spectrometry (Py-GC/ MS). Samples affected by fire had higher total organic matter content, and this was enriched in aromatic components. Good agreement was observed between the content of refractory organic matter (ROM) determined by TG analysis and the aromatic content measured by ${ }^{13} \mathrm{C}$ NMR. Py-GC/MS demonstrated the presence of aromatic compounds in samples rich in black carbon, the absence of furans (derived from carbohydrates) in soils affected by fire, and the detection of methoxyphenols (derived from lignin) in artificially charred grass and wood. Some of the characteristic peaks obtained by analytical pyrolysis in combination with TG analysis and NMR ${ }^{13} \mathrm{C}$ spectra could be used as markers in the detection of black carbon. This is the first study in which TG-differential scanning calorimetry (DSC)-IRMS has been used to detect black carbon formed during artificial smoldering and natural combustion processes.
\end{abstract}

Abbreviations: ${ }^{13} \mathrm{C}$ NMR, Solid State ${ }^{13} \mathrm{C}$ Nuclear Magnetic Resonance; IRMS, isotope ratio mass spectrometer; Py-GC/MS, analytical pyrolysis; ROM, refractory organic matter; TG, Thermogravimetry.
$\mathrm{B}$ lack carbon produced by incomplete combustion of fossil fuels and biomass, is a ubiquitous form of ROM widely distributed in the environment. There is no a unique structure accepted for this complex material. Heidenreich et al. (1968) reported for the first time the "onion-like" concentric microtexture of "carbon black." In general, it is accepted that black carbon consists of complex polyaromatic condensed structures (Massiello, 2004).

The global production of black carbon has been estimated to be between 50 and $270 \mathrm{Tg} \mathrm{yr}^{-1}$ with as much as $80 \%$ of

Soil Sci. Soc. Am. J. 72:258-267

doi:10.2136/sssaj2007.0031

Received 22 Jan. 2007.

*Corresponding author (jmrosa@irnase.csic.es).

(C) Soil Science Society of America

677 S. Segoe Rd. Madison WI 53711 USA

All rights reserved. No part of this periodical may be reproduced or transmitted in any form or by any means, electronic or mechanical, including photocopying, recording, or any information storage and retrieval system, without permission in writing from the publisher. Permission for printing and for reprinting the material contained herein has been obtained by the publisher. this remaining as residues in soil (Kuhlbusch, 1998; Suman et al., 1997). Wildfires are a particular source of resilient carbon in soil, including black carbon. (González-Pérez et al., 2004). In Mediterranean areas forest fires are a frequent and recurrent phenomena during the hot and dry summer months where temperatures often exceed $40^{\circ} \mathrm{C}$ (Moreno and Oechel, 1995). From 1980 to 2004 , more than $90 \%$ of all forest fires in the European Union occurred in the Mediterranean countries, and $38.25 \%$ of burnt areas were located in Spain. Between 1991 and 2004, the mean area affected by fires in the Andalusian region

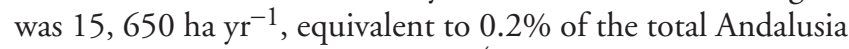
area and producing up to $3 \times 10^{4} \mathrm{Mg}$ of black carbon each year (González-Pérez et al., 2002). As biomass is charred, the relative proportion of aryl and O-aryl structures (aromaticity) increases with a concomitant loss in carbohydrate and lignin structures (Knicker et al., 1996; Baldock and Smernik, 2002). The micromorphological and chemical features of charred biomass are described in Schmidt and Noack (2000), Poirier et al. (2000, 2002). It behaves as a highly aromatic material and, in the case of that formed by vegetation fires, often consists of randomly oriented stacks of a few graphitic layers. In any case, the final black carbon product is not necessarily graphitic, and 
this black material, even when completely amorphous, contains a substantial alkyl domain and a considerable oxygen content (endocyclic or lactone-like; Poirier et al., 2002; Almendros et al., 2003).

Despite recent advances in research pertaining to black carbon in view of its environmental importance as a soil carbon reservoir, very little is known in detail about its structure, distribution and environmental reactivity. There are ambiguities concerning its origin, its molecular structure and how it is isolated from potentially interfering matrix. Black carbon is widely regarded not as a pure substance but rather as a material within a structural and physicochemical continuum with varying stability and character (Massiello, 2004), and isolation for study presents serious experimental constraints. A wide range of analytical approaches has been proposed for the isolation of black carbon from different matrices (Schmidt and Noack, 2000), but the characteristics of black carbon in environmental samples may differ from method to method depending on the sample treatment used. Also, variations in black carbon concentration have been observed when using different techniques to examine the same material, mainly because each analytical method may be optimized to detect a particular form of black carbon (Schmidt et al., 2001).

At present, there is not a single accepted method able to quantify black carbon, that is capable of providing the analytical data required to estimate its contribution to terrestrial and sedimentary carbon fluxes and the global carbon cycle in general. In recognition of this, this paper considers the potential of the combined use of analytical pyrolysis, thermal analysis, and solid state ${ }^{13} \mathrm{C}$ NMR to determine the amount and composition of black carbon within soils.

Analytical Py-GC/MS has been successfully used in previous studies on the refractory fraction of soils (Quénéa et al., 2005; Poirier et al., 2000) and sediments that contain black carbon (Simpson et al., 2005). Py-GC/MS has also been used to characterize resilient organic matter (Martín et al., 1995; Fabbri et al., 1996; Hatcher and Clifford, 1994; González-Vila et al., 2001a), cuticular resilient plant materials (Del Río and Hatcher, 1998; McKinney et al., 1996), and as a complementary tool to analyze biomarkers in kerogens (González-Vila et al., 2001b) and fossil remains (Almendros et al., 1999).

Thermal analysis methods, specifically TG-DSC, have been used to characterize chemical changes in the organic matter fractions of soils and sediments, degraded plant tissue, and compost (Dell'Abate et al., 2000, 2003; Lopez-Capel et al., 2005a, 2005b; 2006a, 2006b). TG-DSC has also been used to compare the proportions of reactive and more stable components in organic matter fractions under contrasting conditions (Lopez-Capel et al., 2005a, 2005b, 2006b), and recently to different forms of black carbon (Leifeld, 2007). Extending the capability of thermal analysis, the coupling of an isotope ratio mass spectrometer (IRMS) to a thermal analysis system (TG-DSC-IRMS; Manning et al., 2005) allows measurements of $\mathrm{C}$ stable isotope ratios to be made on the gas evolved from organic $\mathrm{C}$ within a sample, quantifying each fraction from the measured weight loss as it is combusted experimentally.

Solid-state ${ }^{13} \mathrm{C}$ NMR has been widely used in the characterization of ROM from soils and sediments, and more recently has been used in combination with analytical flash pyrolysis to recognize charred biomass in soils affected by wildfires (González-Vila et al., 2002).

The work reported in this paper describes fire-affected soils from Andalusian Mediterranean forests. Selected soils that contain black carbon and artificially charred materials were analyzed to detect and characterize black carbon in complex matrices. A combination of Py-GC/MS, TG-DSC-IRMS, solid state ${ }^{13} \mathrm{C} N M R$, and elemental analyses was performed to characterize the selected reference materials, providing both structural and quantitative information for recognizable bulk fractions within the sample.

\section{MATERIALS AND METHODS Samples Description}

Three different sample sets were analyzed:

A) Laboratory-produced black carbon-rich materials prepared from plant material as reference materials were supplied by the Geography Dep. University of Zurich, Switzerland (Dr. M. Schmidt). These consisted of grass char (Oryza sativa) from risotto rice straw (Sample GCh) and a wood char obtained from chestnut wood (Castanea sativa; Sample WCh) produced at $450^{\circ} \mathrm{C}$ for $5 \mathrm{~h}$ in an inert nitrogen atmosphere (Hammes et al., 2006).

B) Black carbon-rich soils from agricultural sites affected by vegetation burning; a light sandy clay Chernozemic Mollisol (sample ChMs) sampled at a 20- to 60-cm depth in the Hildsheim-Braunschweig region (Germany), and a sandy clay Wiesenboden Vertisol (Sample WVs) sampled at a 0 - to $10-\mathrm{cm}$ depth at Urrbrae (South Australia). These samples were supplied by the CSIRO (Dr. Jan Skjemstad; PMB 2, Glen Osmond, SA 5064, Australia).

C) Black carbon-rich soils from natural forests affected by wildfires, sampled as part of this study from Castaño del Robledo, Southern Spain (sample BS), which was burnt in 2004. Samples were taken from the A horizon $(0-10 \mathrm{~cm})$ after removing the litter; three subsamples were taken in an area of about $20 \mathrm{~m}^{2}$ and mixed in a composite sample, air-dried, and crushed to pass a 2-mm sieve. Also a soil sample located from a near-by fire unaffected area, $<2 \mathrm{~km}$ distant, and with the same environmental conditions as Sample BS was taken and used as control soil (Sample CS). Both soils are Dystric Cambisols (ISSS Working Group, 1998), located at over $830 \mathrm{~m}$ above sea level, developed under chestnut trees (Castanea Sativa) and maritime pine (Pinus pinaster) together with typical Mediterranean bush vegetation (Ericaceae, Cistaceae, Lamiaceae, Leguminoseae). This region has a Mediterranean climate with dry and hot summers. Average annual rainfall for the area is $700 \mathrm{~mm}$ and the mean annual temperature is $18^{\circ} \mathrm{C}$.

\section{Experimental Methods \\ Elemental Analysis and Stable Carbon Isotope Determination}

Carbon and $\mathrm{N}$ contents were determined in duplicate bulk samples by dry combustion using a CHN auto-analyser (CHN NA 1500, Carlo-Erba) coupled to an isotope ratio mass spectrometer (VG Sira 10) to determine the ratio of stable $C$ isotopes $\left(\delta^{13} C\right)$. Results for isotope abundance are reported in per mil (\%o) notation relative to the Pee Dee Belemnite standard (PDB). Analytical precision for bulk isotope measurements was $\pm 0.3 \%$. 


\section{Thermogravimetric Analyses}

TG-DSC-IRMS was performed using a Netzsch STA 449C Jupiter thermal analysis system in which the gas outlet is coupled by a capilliary via a PDZ ANCA S/L interface module to a PDZ Europa 20:20 isotope ratio mass spectrometer system (Lopez-Capel et al., 2005b). A soil sample (30 mg) or artificially charred material $\left(10 \mathrm{mg}\right.$ ) was placed in an $\mathrm{Al}_{2} \mathrm{O}_{3}$ crucible, and heated at $20^{\circ} \mathrm{C} \mathrm{min}{ }^{-1}$, from 30 to $650^{\circ} \mathrm{C}$ under a flow of $20 \% \mathrm{O}_{2}$ in $\mathrm{He}\left(50 \mathrm{~cm}^{3} \mathrm{~min}^{-1}\right)$ and from 650 to $1000^{\circ} \mathrm{C}$ under a flow of He only.

The TG and DSC signals were exported to the NETZSCH software for analysis versus temperature. In accordance with previous descriptions (Dell'Abate et al., 2000; Lopez-Capel et al., 2005a), thermal analysis allows distinction of labile soil organic matter (decomposes between 200 and $380^{\circ} \mathrm{C}$ ), recalcitrant organic matter (weight losses observed between 380 and $475^{\circ} \mathrm{C}$ ), and ROM (decomposes between 475 and $650^{\circ} \mathrm{C}$ ). The weight losses observed within these temperature ranges are referred to respectively as Exo 1, Exo 2, and Exo 3, as relative proportions of the total weight loss (Exotot) between 200 and $650^{\circ} \mathrm{C}$ (Dell'Abate et al., 2000).

For IRMS analysis, six discrete evolved gas samples were taken during the TG-DSC heating profile between 300 and $600^{\circ} \mathrm{C}$. The gas samples correspond to the gas evolved at 300, 350, 420, 450, 520, and $550^{\circ} \mathrm{C}$. These temperatures correspond to reactions detected by DSC that relate to thermal decomposition of different OM fractions. Reference $\mathrm{CO}_{2}$ gas $\left(\delta^{13} \mathrm{C}=-35.24 \%\right.$ ) was sampled six times during each run. Using this technique, carbon isotopic values were measured to a precision of $\pm 0.5 \%$.

\section{Pyrolysis-Gas Chromatography-Mass Spectrometry}

Analytical pyrolysis (Py-GC/MS) was performed in a double shot pyrolyzer (Model 2020, Frontier Laboratories, Ltd. Fukushima, Japan) directly connected to an Agilent 6890 GC-MS system (Agilent, Santa Clara, CA). The double shot pyrolyzer allows thermal desorption of samples (at subpyrolysis temperature) before pyrolysis, and so allows the sequential examination of the products released by thermal desorption and by thermal cracking from the same sample. This technique has been used recently for the analysis of a wide spectrum of complex carbonaceous matrices including fossil OM, polymers, algal, and higher plant materials (Yoshioka and Ishiwatari, 2002; Herrera et al., 2003; Lee et al., 2005; Camean et al., 2005; Arias et al., 2005).

Depending on $\mathrm{C}$ content, for all experiments between 0.4 to $2 \mathrm{mg}$ of a sample were placed in small platinum capsules. Direct flash pyrolysis at $500^{\circ} \mathrm{C}$ was applied for every sample except for the Mediterranean soils (BS and CS) in which a previous thermal desorption step at $280^{\circ} \mathrm{C}$ (first shot) was performed before the pyrolysis. The desorption step was specifically applied in the BS and CS samples to detect molecular markers of changes in the thermolabile organic matter caused by fire. Previous thermal analysis studies showed a loss

Table 1. Carbon, $\mathrm{N}, \mathrm{C} / \mathrm{N}$ ratio and $\delta^{13} \mathrm{C}$ values of bulk samples.

\begin{tabular}{|c|c|c|c|c|c|}
\hline Sample & Ref. & $\mathbf{N}$ & C & $\mathrm{C} / \mathrm{N}$ & ${ }^{13} \mathrm{C}$ \\
\hline & \multicolumn{4}{|c|}{$-\mathrm{g} \mathrm{kg}^{-1}-$} & $\%$ \\
\hline Chernozemic Mollisol & ChMs & 1.8 & 19.8 & 10.9 & -25.9 \\
\hline Wiesenboden Vertisol & WVs & 2.3 & 31.7 & 13.8 & -22.2 \\
\hline Wood char & WCh & 1.2 & 720.4 & 596.7 & -26.4 \\
\hline Grass char & GCh & 13.2 & 582.5 & 44.2 & -26.7 \\
\hline Dystric Cambisol (Control) & $\mathrm{CS}$ & 1.9 & 24.4 & 12.7 & -25.9 \\
\hline Dystric Cambisol (Burnt) & BS & 3.0 & 34.2 & 11.4 & -27.1 \\
\hline
\end{tabular}

of thermolabile organic constituents in fire-affected soils (Knicker et al., 2005a), and analysis of desorbed volatiles at subpyrolysis temperatures (up to $350^{\circ} \mathrm{C}$ ) provides information concerning thermolabile components, whereas pyrolysis at higher temperatures releases compounds derived from components with higher thermal stability (Quénéa et al., 2005).

During desorption the sample capsule was introduced in the furnace preheated at $100^{\circ} \mathrm{C}$ and the temperature was raised to $280^{\circ} \mathrm{C}$ at a rate of $20^{\circ} \mathrm{C} \mathrm{m^{-1 }}$, and held at $280^{\circ} \mathrm{C}$ for $1 \mathrm{~min}$. The gases evolved during pyrolysis were separated using a fused silica HP 5MS capillary column $(30 \mathrm{~m} \times 250 \mu \mathrm{m} \times 0.25 \mu \mathrm{m}$ i.d. $)$. The detector consisted of an Agilent 5973 mass selective detector (electron impact at $70 \mathrm{eV}$ ). GC/ MS conditions were the same for all samples; oven temperature was held at $40^{\circ} \mathrm{C}$ for $1 \mathrm{~min}$ and then increased up to $100^{\circ} \mathrm{C}$ at $30^{\circ} \mathrm{C} \mathrm{min}{ }^{-1}$, from 100 to $500^{\circ} \mathrm{C}$ at $20^{\circ} \mathrm{C} \mathrm{min}^{-1}$ and isothermal at $500^{\circ} \mathrm{C}$ for $2 \mathrm{~min}$. The carrier gas used was He with a controlled flow rate of $1 \mathrm{~mL} \mathrm{~min}^{-1}$. The identification of individual compounds was achieved by single ion monitoring for different homologous series, low-resolution mass spectrometry and comparison with published and stored data (NIST and Wiley libraries).

\section{Solid-State ${ }^{13} \mathrm{C}$ NMR Spectroscopy}

The solid-state cross polarization magic angle spinning (CPMAS) ${ }^{13}$ C NMR spectra were obtained on a Bruker DSX 200 NMR spectrometer, using the standard ramp-CP pulse program (Cook et al., 1996; Dria et al., 2002). To concentrate the organic material before analysis by removal of the mineral matrix, soil samples were pretreated with $10 \%$ hydrofluoric acid, washed three times with distilled water and freeze-dried. This procedure also removes paramagnetic compounds (Rumpel et al., 1998) and increases the signal/noise ratio in CP MAS ${ }^{13} \mathrm{C}$ NMR by reducing interference from iron-bearing minerals (Gélinas et al., 2001; Schmidt et al., 1997).

Approximately $300 \mathrm{mg}$ of dry sample was packed into a 7-mm zirconium rotor with a Kel-F cap. The spectrum was collected using a spinning speed of $6.8 \mathrm{KHz}$. The ${ }^{13} \mathrm{C}$ chemical shifts were referenced to external tetramethylsilane $(=0 \mathrm{ppm})$ and adjusted with glycine (= $176.04 \mathrm{ppm}$ ) as an external standard. The acquisition parameters were as follows: spectral frequency of $50.3 \mathrm{MHz}$ for ${ }^{13} \mathrm{C}$ and $200 \mathrm{MHz}$ for ${ }^{1} \mathrm{H}$. A contact time $\left(t_{\mathrm{c}}\right)$ of $1 \mathrm{~ms}$ was used. For quantification, the solidstate ${ }^{13} \mathrm{C}$ NMR spectra were integrated using the integration software routine of the spectrometer provided by Bruker. The relative proportion of organic $\mathrm{C}$ functional groups was determined by integration of the signal intensity of each spectrum over given chemical shift regions as described by Wilson (1987).

\section{RESULTS AND DISCUSSION Elemental Analyses and Carbon/Nitrogen Ratio}

Elemental $\mathrm{C}$ and $\mathrm{N}$ contents and $\mathrm{C} / \mathrm{N}$ ratios are shown in Table 1. Higher $\mathrm{C}$ and lower $\mathrm{N}$ content were observed for wood char (WCh) compared with grass char (GCh)., and the $\mathrm{C} / \mathrm{N}$ ratio is an order of magnitude greater for the wood char, as was reported recently for the same samples by Hammes et al. (2006). In the case of the agricultural soil samples, slightly higher $\mathrm{C}$ and $\mathrm{N}$ contents, and $\mathrm{C} / \mathrm{N}$ ratio, were obtained for the vertisol (WVs) as compared with the mollisol (ChMs). Concerning the Mediterranean soils, a small decrease in $\mathrm{C} / \mathrm{N}$ ratio is observed in the fire-affected soil (BS; 12.7), compared with the unburnt soil (CS; 11.4). Although this reduction in $\mathrm{C} / \mathrm{N}$ ratio is unlikely to be significant, it has been suggested that decreases in the $\mathrm{C} / \mathrm{N}$ ratio observed in some soils after 
natural fires or controlled heating could be due to the accumulation of newly formed recalcitrant heterocyclic $\mathrm{N}$ in addition to aromatic C forms (Almendros et al., 2003), consistent with the findings of Knicker et al. (1996, 2005a) using solid state ${ }^{13} \mathrm{C}$ and ${ }^{15} \mathrm{~N}$ NMR analysis.

\section{Thermal Analysis (TG-DSC)}

Thermogravimetric measurements (Fig. 1) show three different behaviors corresponding to each sample type, according to the changes in slope of the weight loss curve determined by the first derivative of the thermogravimetric curve (TGD). Observed weight losses are presented in Table 2. Reflecting its thermal stability, organic matter can be divided into three main groups in terms of the proportions of labile (Exo 1), recalcitrant (Exo 2), and refractory (Exo 3) components, in accordance with previous practice (Lopez-Capel et al., 2005a, 2006a; Manning et al., 2005; Plante et al. 2005; Dell'Abate et al., 2003). As explained by Lopez-Capel et al. (2005a), labile organic matter (Exo 1) is dominated by aliphatic $\mathrm{C}$ and carbohydrates; cellulose decomposes in this interval. Recalcitrant organic matter (Exo 2) reflects aromatic-rich components; lignin decomposes in this interval. Finally, ROM (Exo 3) includes polycondensed aromatic carbon; black carbon is reported for this decompositional temperature range.

Major weight losses were found in artificially charred materials. In the temperature range associated with recalcitrant organic matter $\left(380-475^{\circ} \mathrm{C}\right)$ Exo 2 accounted for $65.1 \%$ in GCh and $30.7 \%$ in $\mathrm{WCh}$, and in the temperature range associated with ROM $\left(475-650^{\circ} \mathrm{C}\right)$ Exo 3 accounted for 3.8\% in GCh and $56.8 \%$ in WCh. These data are consistent with the known formation of char from cellulose (Kawamoto and Saka, 2006), which is the dominant constituent of the grass starting material.

For the soil samples, low weight losses were found in the soils, but with a clear difference between them. The ChMs showed higher total TG loss (6.14\%) mainly in the Exo 2 region $(49.5 \%$ of the total loss) whereas WVs had the lowest TG loss $(1.61 \%)$ with a maximum in the Exo3 region $(39.8 \%$ of the total loss). In samples studied from the Mediterranean forest soils, TG results reflected differences between the CS and the BS sample. The proportion of the total weight loss associated with ROM (Exo3) is greater for the BS reflecting its black carbon content. In the Exo 3 region, CS presented a $19.9 \%$ and $\mathrm{BS}$ a $31.4 \%$ weight loss indicating a strong effect of the fire on the black carbon content and on the refractory nature of the remaining soil organic matter. Total weight loss in BS (14.88\%) was lower than in CS (29.55\%). This result is consistent with the high temperatures that the BS has been subjected to during the fire event, reducing the content of labile organic matter and increasing the thermal recalcitrance of the soil organic matter.

In addition to the observed weight losses, DSC exothermic peaks (Fig. 1) at around $350^{\circ} \mathrm{C}$ can be attributed to decomposition of labile materials, including cellulose decarboxylation, reported for the thermal analysis of several Mediterranean plants (Kaloustian et al., 2001), and peaks at $450-500^{\circ} \mathrm{C}$ to combustion of the recalcitrant organic matter and/or char materials (Lopez-Capel et al., 2005a, 2005b). A third exothermic peak at 550 to $650^{\circ} \mathrm{C}$ can be attributed to refractory forms of organic matter. This third peak is character-

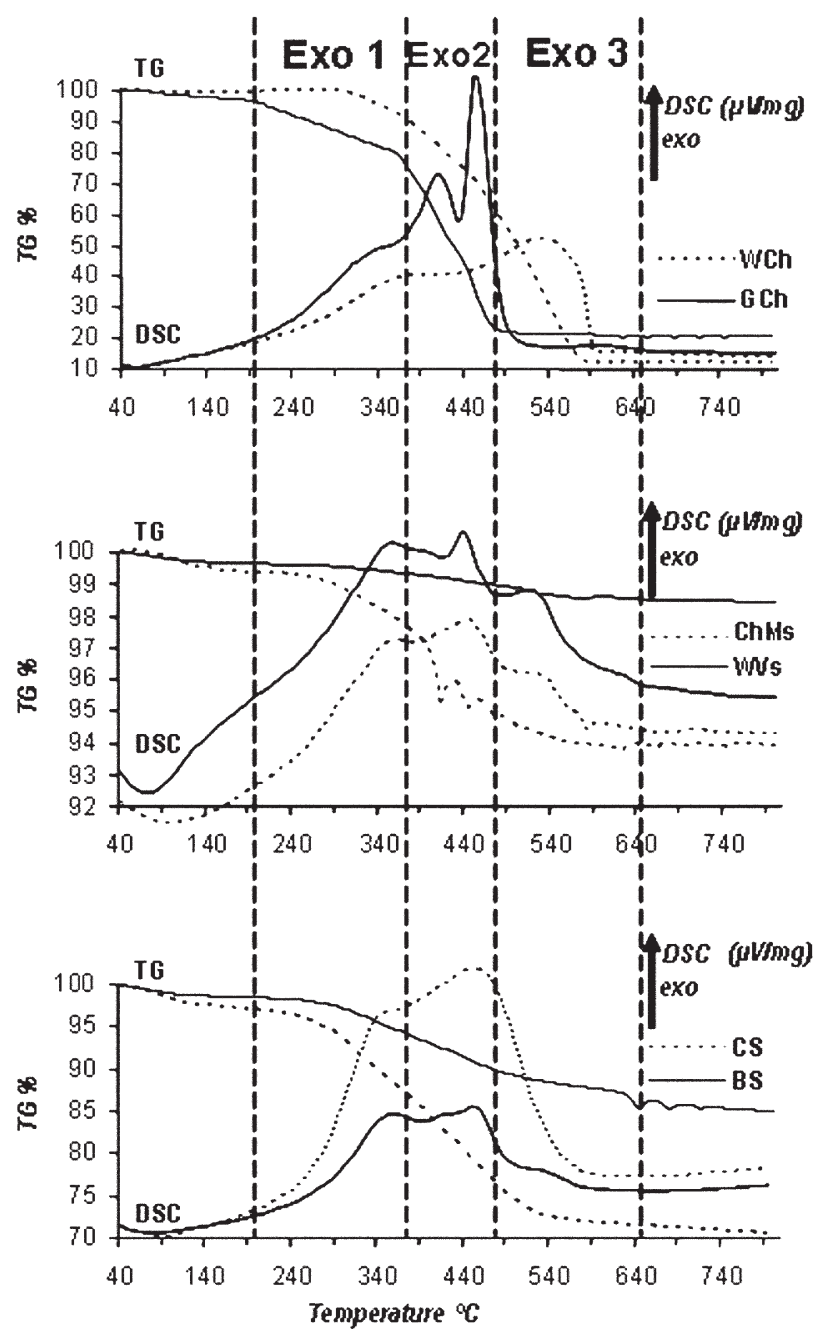

Fig. 1. Weight loss Thermograms (TG) and differential scanning calorimetric (DSC) curves of samples within the range from 40 to $800^{\circ} \mathrm{C}$.

istic of materials such as black carbon and/or kerogen. In detail, sample GCh clearly showed a char component equivalent to that observed for charred cellulose (Lopez-Capel et al., 2005a), whereas the WCh includes a less well defined (broader DSC peak) that breaks down at higher temperatures during thermal analysis. The agricultural soil samples showed two exothermic peaks at around 350 and $460^{\circ} \mathrm{C}$, corresponding to labile and recalcitrant organic matter, respectively. They also showed an

Table 2. Comparative thermogravimetry (TG) weight loss (\%) for the temperature interval $50-800^{\circ} \mathrm{C}$ (Total TG loss), direct and relative weight losses $(\%)$ of temperature intervals Exo 1 $\left(200-380^{\circ} \mathrm{C}\right)$, Exo $2\left(380-475^{\circ} \mathrm{C}\right)$ and Exo $3\left(475-650^{\circ} \mathrm{C}\right)$.

\begin{tabular}{lcccccc}
\multicolumn{1}{c}{ Range T $\left({ }^{\circ} \mathbf{C}\right)$} & ChMst & WVs & WCh & GCh & CS & BS \\
\hline Total TG loss & 6.14 & 1.61 & 88.05 & 79.47 & 29.55 & 14.88 \\
200-380 & 1.87 & 0.34 & 10.88 & 23.46 & 10.69 & 4.59 \\
$380-475$ & 2.70 & 0.34 & 26.95 & 49.42 & 9.75 & 3.97 \\
$475-650$ & 0.89 & 0.45 & 49.95 & 2.99 & 5.09 & 3.91 \\
Exo 1 & 34.2 & 30.1 & 12.4 & 30.9 & 41.9 & 36.8 \\
Exo 2 & 49.5 & 30.1 & 30.7 & 65.1 & 38.2 & 31.8 \\
Exo 3 & 16.3 & 39.8 & 56.8 & 3.9 & 19.9 & 31.4 \\
\hline
\end{tabular}

tChMs: Mollisol sample; WVs: Vertisol sample; WCh: Artificially charred chestnut wood material; GCh: Artificially charred grass material; CS: Control Mediterranean forest soil; BS: Burnt Mediterranean forest soil. 


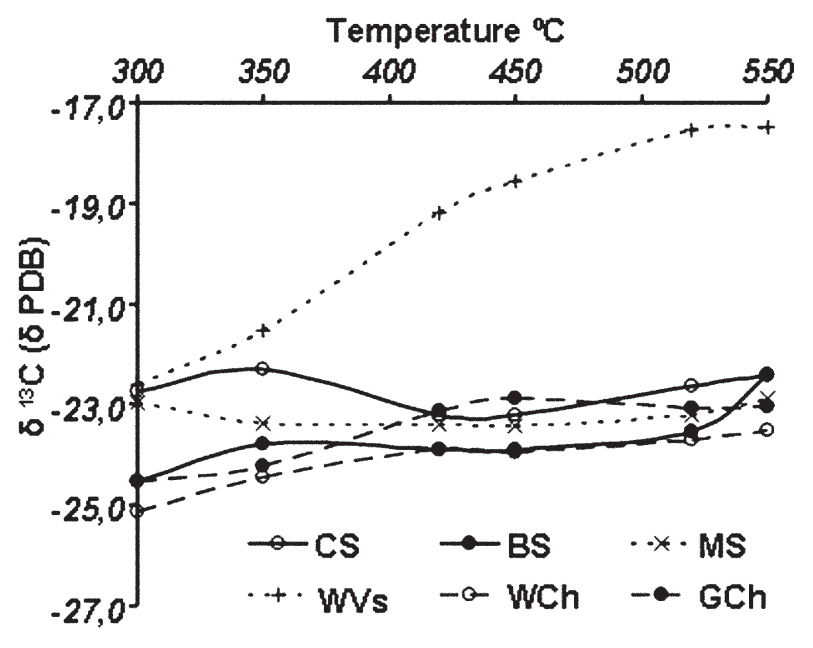

Fig. 2. $\delta{ }^{13} \mathrm{C}$ values of studied samples measured at 300, 350, $420,450,520$, and $550^{\circ} \mathrm{C}$ during thermal degradation as measured by Thermogravimetry-Isotopic Ratio Mass Spectrometer (TG-IRMS).

endothermic peak at $80^{\circ} \mathrm{C}$ that could correspond to loss of water from clays. Differences between the DSC traces of control and fire-affected soil include observation of a shoulder at $500-600^{\circ} \mathrm{C}$ in the BS that could correspond to the presence of black carbon-like material, which is absent in the CS. All six samples showed the main exothermic peak at $430-470^{\circ} \mathrm{C}$, within the recalcitrant organic matter range and the shoulder at $500-600^{\circ} \mathrm{C}$ (except for GCh and CS).

In the case of the Mediterranean soil samples, TG-DSC traces in Fig. 2 showed a decrease in labile compounds and an increase in refractory compounds after forest fire. Different relative weight losses summarized in Fig. 1 and Table 2 confirm that there is a higher proportion of refractory soil organic matter after a forest fire. Figure 1 also shows differences between the two artificially charred material samples demonstrating clear differences in the resistance to thermal oxidation of the GCh and WCh samples.

\section{Stable Isotopic Carbon-13 Measurements}

Figure 2 shows the $\delta^{13} \mathrm{C}$ analysis results obtained using TG-DSC-IRMS for different temperature ranges. In general, bulk $\delta^{13} \mathrm{C}$ values are approximately 2 to $4 \%$ more negative than those determined using TG-DSC-IRMS (Lopez-Capel et al., 2005b), consistent with this study (see Table 1). The $\delta^{13} \mathrm{C}$ carbon value of the soils depends largely on the type of plant that grows on them. Soil organic matter derived from $\mathrm{C}_{3}$ plants has $\delta^{13} \mathrm{C}$ values between about -23 to $-34 \%$ with a mean close to $-27 \%$, while $\mathrm{C}_{4}$ plants range from -9 to $-17 \%$ (Smith and Epstein, 1971; Benedict, 1978). The $\delta^{13} \mathrm{C}$ values show little variation for components with differing thermal stability, but two trends are observed:

All samples other than WVs show similar $\delta^{13} \mathrm{C}$ values for $\mathrm{CO}_{2}$ evolved during the thermal analysis experiment, with values of approximately -23 to $-24 \%$ (compared with bulk values of -26 to $-27 \%$ ), that are in the range reported for natural combustion products and anthropogenic black carbon (Glaser et al., 2005). Within this group, samples GCh and BS increase slightly. In contrast, sample WVs is clearly different in character, with much heavier $\delta^{13} \mathrm{C}$ values for the more refractory components $(-18 \%$ o compared with $-22.2 \%$ o for the bulk value for this sample). This observation suggests that the Wiessenboden Vertisol could contain refractory $\mathrm{C}$ derived from $\mathrm{C}_{4}$ plants.

No significant differences were observed for the artificially charred materials. This is because rice (origin material of the $\mathrm{GCh}$ ) and chestnut (origin material of the WCh) are $\mathrm{C}_{3}$ photosynthetic plants.

\section{Pyrolysis-Gas Chromatography/Mass Spectrometry}

Clear differences were found when comparing the pyrograms obtained from the three different groups of samples (Fig. 3 and Table 3). Remarkably simple total ion current chromatograms (TIC) were obtained from the vertisol (WVs) and mollisol (ChMs) samples, with a greater proportion of carbohydratederived compounds in the Vertisol (i.e., 2,5-dihidrofuran, 3-methyl-2,5-dihidrofurane, and 2,5-dimethylfuran) which are totally absent in the Mollisol. This different pyrolytic behavior has been previously reported by Leinweber et al. (1999), and is also in agreement with the different behavior observed by TG. It could arise from the special features of vertisol formation, in which there are periodic additions of organic matter to the soil during dry periods due to changes in moisture content and volume (vertilization process).

Differences were also observed in the TIC chromatograms of the artificially charred materials. There is a strong signal for levoglucosan in WCh (Peak C9) and this, together with the presence of other carbohydrate-derived compounds (i.e., furan and alkylfuran compounds), may indicate an incomplete charring of the sample. Short-chain alkanes/enes $\left(\leq \mathrm{C}_{16}\right)$ are present in the GCh. Lignin-derived guaiacol is detected only in sample WCh (Peak L1) and absent in GCh, corresponding to the different nature of the samples.

Conspicuous differences in pyrolysate composition, between the first and the second shot, were found when studying the Mediterranean forest soil by double-shot pyrolysis. Thermal desorption of the sample at $280^{\circ} \mathrm{C}$ released compounds with carbohydrate origin $\left(\mathrm{C}_{5}, \mathrm{C}_{6}, \mathrm{C}_{11}\right.$, and $\left.\mathrm{C}_{12}\right)$ in the control soil that are absent in the fire-affected soil. Pyrolysis at $500^{\circ} \mathrm{C}$ shows also important qualitative and quantitative differences between the control and the fire-affected Mediterranean soil, such as the presence of a complete pattern of alkanes (from $\mathrm{C}_{13}$ to $\mathrm{C}_{25}$ ) and carbohydrate origin compounds in CS revealing the presence of labile organic matter in this sample. Ligninderived compounds were also detected in CS. The BS pyrogram consisted mainly of aromatic compounds and N-containing aromatic compounds (Peaks 2, P2, 42) that are absent in CS, which could indicate $\mathrm{N}$ enrichment in the organic matter after the fire event. The BS shows a decrease in the amount and variety of identifiable lignin pyrolysis products that can be explained by the heat-induced alteration of the lignin macromolecule to structures with decreasing methoxyphenol/phenol ratio during the forest fire event and the accumulation of resilient, non-pyrolyzable aromatic structures (González-Vila et al., 2001b).

\section{Solid-State Carbon-13 Nuclear Magnetic Resonance Spectroscopy}

Solid-state CPMAS ${ }^{13} \mathrm{C}-\mathrm{NMR}$ spectra and the relative $\mathrm{C}$ distribution among the different functional groups in the studied samples are shown in Fig. 4 and Table 4, respectively. We assume that we do not detect $100 \%$ of the $\mathrm{C}$ with $\mathrm{CP}{ }^{13} \mathrm{C}$ 


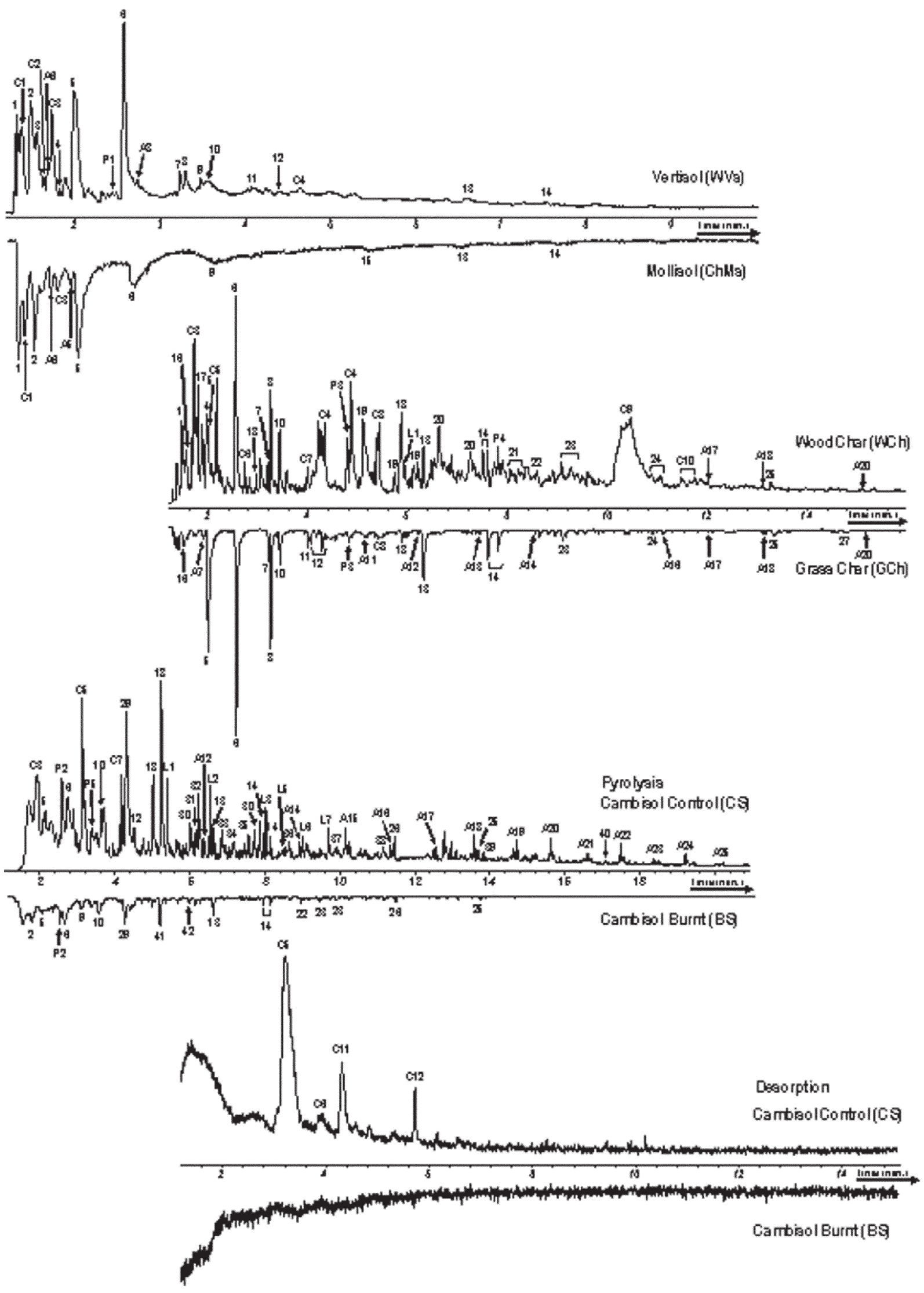

Fig. 3. Total ion chromatograms Pyrolysis-Gas chromatography/mass spectroscopy. The numbers over the peaks refer to compounds listed in Table 3. Flash pyrolysis of the samples was carried on at $500^{\circ} \mathrm{C}$. The desorption step $\left(280^{\circ} \mathrm{C}\right)$ was achieved on Mediterranean soil samples before the pyrolysis step. 
Table 3. Compounds released by pyrolysis-gas chromatography-mass spectrometry (PyGC/MS) from the studied samples.

\begin{tabular}{|c|c|c|c|}
\hline Assignment & Peak label & Assignment & Peak labelt \\
\hline ethanol & 1 & 2,5-dihidrofuran & $\mathrm{C} 1$ \\
\hline pyrazole & 2 & 3-methyl-2,5-dihidrofurane & $\mathrm{C} 2$ \\
\hline propenonitrile & 3 & 2-methylfuran & $\mathrm{C} 3$ \\
\hline cyclohexadiene & 4 & benzofuran & $\mathrm{C} 4$ \\
\hline benzene & 5 & 2,5-dimethylfuran & $\mathrm{C} 5$ \\
\hline toluene & 6 & $x, x, x$-thimethylfuran & $\mathrm{C} 6$ \\
\hline ethylbenzene & 7 & 5-methylfurfural & $\mathrm{C} 7$ \\
\hline o-dimethylbenzene & 8 & x-methylbenzofurane & C8 \\
\hline $\mathrm{m} / \mathrm{p}$-dimethylbenzene & 9 & levoglucosan & C9 \\
\hline styrene & 10 & methyldibenzofurane & $\mathrm{C} 10$ \\
\hline 1,3,5-trimethylbenzene & 11 & 5-methyl-2-furancarboxaldehyde & C11 \\
\hline 1-methylethylbenzene & 12 & 2-furanmethanol & $\mathrm{C} 12$ \\
\hline naphthalene & 13 & 1 methyl-1-H-pirrole & $\mathrm{P} 1$ \\
\hline methylnaphthalene & 14 & pyridine & $\mathrm{P} 2$ \\
\hline benzonitrile & 15 & $x, x, x$-trimethylindane & P3 \\
\hline 1,3-cyclopentadiene & 16 & pentamethylindane & $\mathrm{P} 4$ \\
\hline acetic acid & 17 & 2-methyl-pyridine & P5 \\
\hline methylphenol & 18 & 1-hexene & A6 \\
\hline x,x-xylenol & 19 & 1-methylpentene & A5 branched \\
\hline pyrocatechol & 20 & 1-octene & A8 \\
\hline methylcoumarin & 21 & undecane/ene pair & A11 \\
\hline biphenil & 22 & docecane/ene pair & A12 \\
\hline x, x-dimethylnaphthalene & 23 & tridecane/ene pair & A13 \\
\hline$x, x, x$-trimethylnaphthalene & 24 & tetradecane/ene pair & A14 \\
\hline phenanthrene & 25 & pentadecane/ene pair & A15 \\
\hline fluorene & 26 & hexadecane/ene pair & A16 \\
\hline 1-methylphenanthrene & 27 & heptadecane/ene pair & A17 \\
\hline 5-methyl-1,2,3,4-tetrahydronaphthalene & 28 & octadecane/ene pair & A18 \\
\hline phenol & 29 & nonadecane/ene pair & A19 \\
\hline benzeneacetonitrile & 30 & eicosane/ene pair & $\mathrm{A} 20$ \\
\hline 1-methyl-1H-Indene & 31 & heneicosane/ene pair & $\mathrm{A} 21$ \\
\hline x-ethylphenol & 32 & docosane/ene pair & A22 \\
\hline 4-vinylphenol & 33 & tricosane/ene pair & A23 \\
\hline benzenepropanenitrile & 34 & tetracosane/ene pair & $\mathrm{A} 24$ \\
\hline 1,3-dimethyl-1H-Indene & 35 & pentacosane/ene pair & A25 \\
\hline hexylbenzene & 36 & guaiacol & $\mathrm{L} 1$ \\
\hline octylbenzene & 37 & p-methylguaiacol & $\mathrm{L} 2$ \\
\hline nonylbenzene & 38 & $p$-vinilguaiacol & L3 \\
\hline anthracene & 39 & 1,3,5-trimethoxybenzene & $\mathrm{L} 4$ \\
\hline fluoranthene & 40 & eugenol & L5 \\
\hline acetophenone & 41 & vanillin & L6 \\
\hline benzylnitrile & 42 & isoeugenol & $\mathrm{L} 7$ \\
\hline
\end{tabular}

tPeak labels C, P, L and An refers to molecules derived from carbohydrates, peptides, lignin, and alkanes/alkenes, respectively.

NMR, as this is simply not possible due to losses caused by relaxation or incomplete CP. However, according to Knicker et al. (2005b), the detectable $\mathrm{C}$ intensity of the different signals at $t_{\mathrm{c}}=1 \mathrm{~ms}$ for soil organic material and char are comparable and vary between approximately 80 and $85 \%$. Those data lead to the conclusion that for soil organic materials and charred vegetation, the intensity distributions obtained with CP-MAS ${ }^{13} \mathrm{C}$ NMR at $t_{\mathrm{c}}=1 \mathrm{~ms}$ representatively reflect the chemical composition of the samples.

The ${ }^{13} \mathrm{C}-\mathrm{NMR}$ region between 45 and $0 \mathrm{ppm}$ is assigned to alkyl C, including dehydroxylated lignin side chains, amino acid residues, lipids and parafinic structures. No differences were observed in the alkyl-C region within each pair of the studied samples, which was usually dominated by signal peaking at 28-30 ppm, typical of the internal methylene $\mathrm{C}$ in long alkyl chains. In Sample GCh the peak at $14 \mathrm{ppm}$ is the only peak found in this region supporting the presence of short-chain alkyl structures as was also seen by Py-GC/MS. Comparing BS and CS NMR spectra, the pattern for the burnt sample is recognizable by a relative higher intensity in the aromatic C region (160-140 ppm). The spectrum of CS also shows higher intensity in the chemical shift region between 110 and $60 \mathrm{ppm}$, commonly assigned to $\mathrm{O}$-alkyl $\mathrm{C}$ atoms in carbohydrate-derived structures, confirming the data obtained by Py-GC/ MS. The intense signal at $72 \mathrm{ppm}$ is typical for $\mathrm{C}_{2} / \mathrm{C}_{3}$ carbons in glycopyranosides (Lüdemann and Nimz, 1973). This signal was also detected clearly in the spectra of the reference soils with a little higher contribution in the ChMs as compared with the vertisol (WVs). Well defined signals at 74 and 82 ppm (carbohydrate related signals) appeared in artificially charred wood (WCh) and were absent in grass char (GCh). This result is also in accordance with the strong presence of carbohydrate peaks released by PyGC/MS in Sample WCh.

The formation of condensed aromatic structures by the charring process may be responsible for the high signal intensity in the region 160$110 \mathrm{ppm}$ in the charred materials and the burnt soil. Thermally induced dehydration and selective degradation of carbohydrates and proteinaceous structures are responsible for the accumulation of newly formed aromatic constituents (Almendros et al., 2003). In fact, the probable cyclization of unsaturated structures affects also the intensity of the chemical shift region between 160 and 140 ppm that corresponds to O-substituted aromatic structures, an indication of the presence of lignin-derived structures that are present in every studied sample.

The signal at $155 \mathrm{ppm}$ in sample MS can be attributed to $\mathrm{C}_{3} / \mathrm{C}_{5}$ in syringyl units and the $146-148 \mathrm{ppm}$ signal in WCh, CS, and $\mathrm{BS}$ to $\mathrm{C}_{3} / \mathrm{C}_{4}$ in guaiacyl units. The signal from the methoxyl $\mathrm{C}$ groups in lignin structures is expected to be around 56 ppm (Lüdemann and Nimz, 1973). However, this chemical shift region overlaps with that of $\mathrm{N}$-alkyl C.

There were no noticeable changes in the studied samples for carboxyl/amide and carbonyl C groups (160-185 and 185$245 \mathrm{ppm}$, respectively) but a slight increase in the signal for BS compared with CS. Some weak signals for spinning side bands 


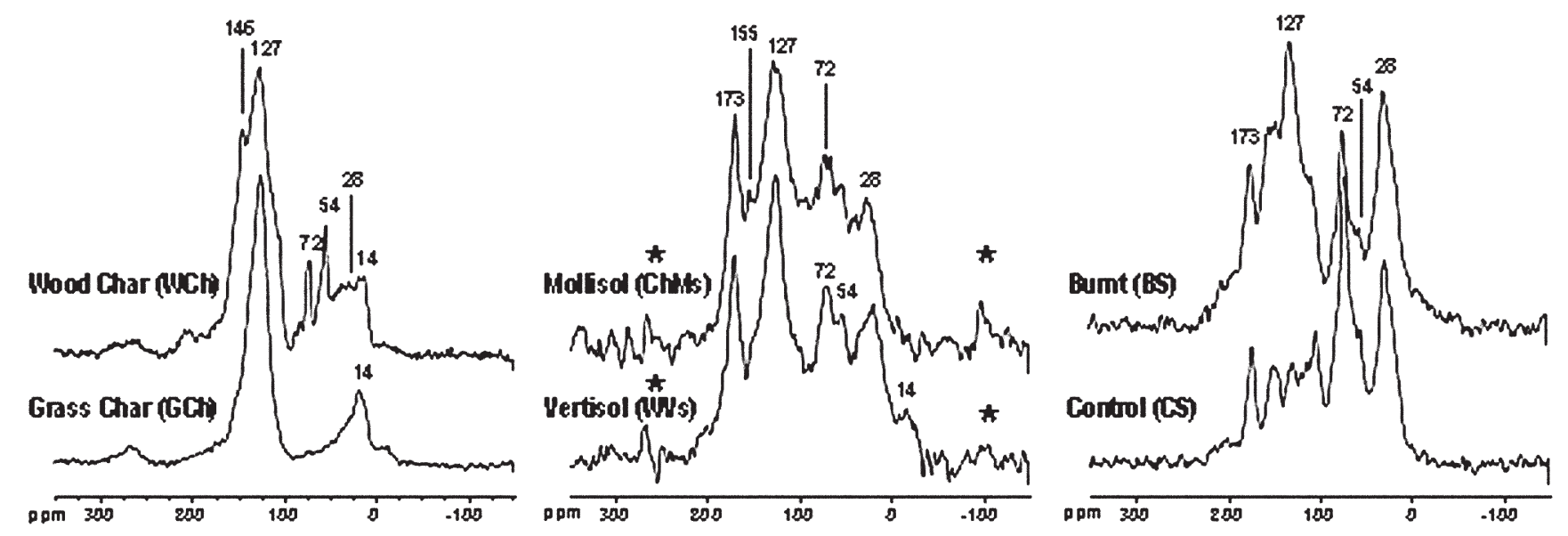

Fig. 4. Solid state ${ }^{13} \mathrm{C}$ NMR spectra of artificially charred materials (wood char and grass char), reference soils (mollisol and vertisol) and Mediterranean soils (control and burnt soil).

for the aromatic structures are also detectable in the regions from 300 to $230 \mathrm{ppm}$ and from 0 to $-50 \mathrm{ppm}$ in MS.

Changes in the chemical composition of the BS when compared with the CS include an enrichment of aromatic/olefinic C (160-110), which increased from $21.5 \%$ of the $C$ to $37.2 \%$. There is also an increase in the signal for lignin residues (140$160 \mathrm{ppm}$ ) that are reported to exhibit a higher resistance toward thermal treatment than $\mathrm{O} / \mathrm{N}$ alkyl groups. Intense charring of carbohydrate moieties has been reported before (Almendros et al., 1990, Pastorova et al., 1994, Knicker et al. (1996); Baldock and Smernik, 2002), with a noticeable decrease in the contribution of O/N-alkyl C (110-45 ppm), from 35.0 to $19.7 \%$ in this study. Weak increases were also observed in the carbonyl $\mathrm{C}$ region in sample BS while the other chemical shift regions remain nearly constant. The increase in aromatic content in BS compared with CS is in agreement with the TG results (Fig. 1) where the relative weight losses $\left(200-650^{\circ} \mathrm{C}\right)$ confirm that there is higher proportion of refractory soil organic matter after the wildfire event. This could also be attributed in part to an increase in pyromorphic humus compounds (Almendros et al., 1984; González-Vila and Almendros, 2003).

NMR spectra from artificially charred materials showed differences that can be summarized in terms of higher aromatic C contribution (110-160 ppm) in the GCh, and lower intensity of the chemical shift region between 110 and $60 \mathrm{ppm}$ (O-alkyl C). In this charred material it is expected that the $\mathrm{C}$ in the $160-110 \mathrm{ppm}$ region would mainly correspond to aromatic structures originating from charred carbohydrate, as suggested by Pastorova et al. (1994) and Almendros et al. (1997). This would indicate higher resistance in the chestnut wood material to the charring process. A specific peak were also identified in WCh at $146 \mathrm{ppm}$ that could indicate presence of guaiacyl units that were absent in GCh. In general good agreement was observed between the aromatic $\mathrm{C}$ content $(140-110$ $\mathrm{ppm}$ ) of the samples and their thermal resilience as measured by the relative weight loss corresponding to Exo 3 in thermogravimetric analysis.
Comparison of results obtained for thermal analysis with those from NMR can be performed, bearing in mind that the number of samples is very limited and that for each technique the proportions of different components has been normalized (hence restricting the independent variability of each data set). Reasonably strong positive correlations are observed between Exo 1 and proportions of alkyl $\mathrm{C}$ determined by NMR (Oalkyl: $r^{2}=0.607$; alkyl: $r^{2}=0.769$; total alkyl: $r^{2}=0.647$; NB there is no correlation with n-alkyl; $r^{2}=0.064$ ), consistent with the attribution of labile organic matter to Exo 1 . Exo 1 correlates negatively with $\mathrm{O}$-aromatic particularly $\left(r^{2}=-0.852\right)$. Similarly, there are weak positive correlations between Exo 2 and aromatic species (aromatic: $r^{2}=0.600$; total aromatic: $r^{2}=$ $0.499)$, and a negative correlation between Exo 2 and ketone $\left(r^{2}\right.$ $=-0.832)$. Exo 3 shows weak positive correlations with ketone $\left(r^{2}=0.569\right)$, O-aromatic $\left(r^{2}=0.506\right)$, but not with aromatic or total aromatic $\left(r^{2}=-0.151\right.$ and-0.024 respectively). Similar correlations are reported by Lopez-Capel et al. (2005a).

Compared with Py-GC/MS, thermal analysis shows that the first shot $\left(280^{\circ} \mathrm{C}\right)$ will provide information concerning the molecular composition of the labile fraction, and that the second shot $\left(500^{\circ} \mathrm{C}\right)$ yields information about the refractory component (assuming that the recalcitrant component decomposes before $500^{\circ} \mathrm{C}$ ). Observed weight losses at higher temperatures suggest that Py-GC/MS does not collect information concerning the most ROM within a sample, which may be stable under the conditions of the analysis.

Table 4. Semi-quantitative assessment (\%) of the different $\mathrm{C}$ types as seen by ${ }^{13} \mathrm{C}$ NMR integration regions. $t$

\begin{tabular}{|c|c|c|c|c|c|c|c|}
\hline Sample & $\begin{array}{c}\text { Ketone, } \\
\text { Aldehyde } \\
\text { 245-185 }\end{array}$ & $\begin{array}{l}\text { Carboxyl, } \\
\text { Amide } \\
\text { 185-160 }\end{array}$ & $\begin{array}{c}\text { O-subst., } \\
\text { Aromatic } \\
160-140\end{array}$ & $\begin{array}{c}\text { Aromatic } \\
140-110\end{array}$ & $\begin{array}{l}\text { O-alkyl } \\
110-60\end{array}$ & $\begin{array}{c}n \text {-Alkyl, } \\
\text { Methoxyl } \\
60-45\end{array}$ & $\begin{array}{l}\text { Alkyl } \\
45-0\end{array}$ \\
\hline ChMs & 2.10 & 12.87 & 10.79 & 25.55 & 26.09 & 7.12 & 15.49 \\
\hline WVs & 3.67 & 13.52 & 10.14 & 27.02 & 21.41 & 6.67 & 17.58 \\
\hline WCh & 3.48 & 5.09 & 18.15 & 39.33 & 13.42 & 6.47 & 14.05 \\
\hline GCh & 1.94 & 4.70 & 13.61 & 55.05 & 6.45 & 2.26 & 16.00 \\
\hline CS & 3.57 & 8.25 & 8.08 & 13.44 & 35.01 & 7.83 & 23.82 \\
\hline BS & 4.95 & 10.89 & 13.41 & 23.80 & 19.65 & 4.63 & 22.67 \\
\hline
\end{tabular}

tC region values are given in ppm; ChMs: Mollisol sample; WVs: Vertisol sample; WCh: Artificially charred chestnut wood material; GCh: Artificially charred grass material; CS: Control Mediterranean forest soil; BS: Burnt Mediterranean forest soil. 
The three techniques, combined, provide consistent information concerning the nature of the sample. ${ }^{13} \mathrm{C}$ NMR and Py-GC/MS provide spectroscopic and chemical evidence concerning molecular structure. But neither technique quantifies discrete pools of soil organic matter. In addition, ${ }^{13} \mathrm{C}$ NMR is a relatively expensive technique and not necessarily amenable for widespread use. Thermal analysis methods can be correlated with those that provide molecular information, and are amenable to routine use in the determination of soil organic matter components (Sebag et al., 2006; Siewert, 2004).

The recalcitrance of soil organic matter as observed using thermal analysis methods reflects its stability within soil environments, with labile, aliphatic-rich, organic matter turning over much more rapidly than recalcitrant or refractory material that is more aromatic. The CP-NMR data are consistent with this, and suggest that the refractory component (produced from wood char and in natural samples) distinguished as Exo 3 in thermal analysis, is the component richest in oxygenated aromatic functional groups. The incomplete combustion of a lignin-rich starting material involves the formation of char with a relatively high $\mathrm{O}$ content (Kawamoto and Saka, 2006) as a consequence of the aromatization of the oxygen-rich cellulose or lignin structures. However, char produced from grass decomposes within the range reported as Exo 2 in this study. From the NMR data, it is the most aromatic-rich of the materials studied here. It appears, therefore, that the thermal stability of the aromatic component produced by charring grass is lower than that produced by charring lignin, perhaps reflecting differences in the extent of cross-linking of the aromatic rings for the two materials.

\section{CONCLUSIONS}

The use of three different and complementary analytical techniques in this study has shown that black carbon, produced by combustion of biomass, can be detected in soils affected by fire. Different information is obtained from the three techniques: thermal analysis estimates quantities of labile, recalcitrant and refractory soil organic matter and these correlate with structural information obtained from ${ }^{13} \mathrm{C}$ NMR. PyGC/MS gives detailed structural information concerning the different components of soil organic matter, distinguishing the characteristics of the labile component from black carbon, and relating to the observations made using ${ }^{13} \mathrm{C} N \mathrm{NMR}$.

For the very limited number of samples investigated here, it is apparent that charring (and subsequent soil processes) appears to have little effect on the carbon isotopic composition of soil organic matter, reflecting $\mathrm{C}_{3}$ plant input. The vertisol sample shows evidence of $\mathrm{C}_{4}$ plant input in the black carbon fraction that is not evident from bulk carbon isotope analysis. The black carbon fraction is enriched in $\mathrm{N}$ compared with $\mathrm{C}$ according to Py-GC/MS analysis, with slight evidence of this from bulk elemental analysis. The proportions of aromatic components determined by thermal methods and by ${ }^{13} \mathrm{C}$ NMR are greater for charred compared with uncharred samples, and for burnt soils, as expected. Overall, the results of this study demonstrate that the combination of techniques used yield valuable information concerning the nature of black carbon in soils, and lend support to routine rapid screening methods that measure weight losses over specific pyrolysis temperature intervals.

\section{REFERENCES}

Almendros, G., J. Dorado, F.J. González-Vila, and F. Martin. 1997. Pyrolysis of carbohydrate-derived macromolecules: Its potential in monitoring the carbohydrate signature of geopolymers. J. Anal. Appl. Pyrolysis 40-41:599-610.

Almendros, G., J. Dorado, F.J. González-Vila, F. Martín, J. Sanz, C. ÁlvarezRamis, and L. Stuchlik. 1999. Molecular characterization of fossil organic matter in Glyptostrobus europaeus remains from the Orawa basin (Poland). Comparison of pyrolytic techniques. Fuel 78:745-752.

Almendros, G., F.J. González-Vila, and F. Martín. 1990. Fire-induced transformation of soil organic matter from an oak forest. An experimental approach to the effects of fire on humic substances. Soil Sci. 149:158-168.

Almendros, G., H. Knicker, and F.J. González-Vila. 2003. Rearrangement of carbon and nitrogen forms in peat after progressive isothermal heating as determined by solid-state 13C- and 15N-NMR spectroscopy. Org. Geochem. 34:1559-1568.

Almendros, G., A. Polo, M.C. Lobo, and J.J. Ibáñez. 1984. Contribución al estudio de la influencia de los incendios forestales en las características de la materia orgánica del suelo: II. Transformaciones del humus por ignición en condiciones controladas de laboratorio. Rev. Écol. Biol. Sol. 21:154- 60.

Arias, M.E., O. Polvillo, J. Rodríguez, J.M. Molina, M. Hernández, F.J. González-Vila, and J.A. González-Pérez. 2005. Effect of different Streptomyces strains on pine wood as seen by Py-GC/MS: Implications for mechanical pulping. J. Anal. Appl. Pyrolysis. 74:138-144.

Benedict, C.R., 1978. The fractionation of stable carbon isotopes in photosynthesis. What's new in Plant Physiol.? 9:13-16.

Baldock, J.A., and R.J. Smernik. 2002. Chemical composition and bioavailability of thermally altered Pinus resinosa (Red pine) wood. Org. Geochem. 33:1093-1109.

Camean, A., I. Moreno, T. Verdejo, F.J. González-Vila, and J.A. GonzálezPérez. 2005. Pyrolytic behaviour of microcystins and microcystin-spiked algal blooms. J. Anal. Appl. Pyrolysis 74:19-25.

Cook, R.L., C.H. Langford, R. Yamdagni, and C.M. Preston. 1996. A modified cross-polarization magic angle spinning $13 \mathrm{C}$ NMR procedure for the study of humic materials. Anal. Chem. 68:3979-3986.

Dell'Abate, M.T., S. Canali, A. Trinchera, A. Benedetti, and P. Sequi. 2000. Thermal methods of organic matter maturation monitoring during a composting process. J. Ther. Anal. Cal. 61:389-396.

Dell'Abate, M.T., A. Benedetti, and P.C. Brookes. 2003. Hyphenated techniques of thermal analysis for characterisation of soil humic substances. J. Sep. Sci. 26:433-440.

Del Río, J.C., and P.G. Hatcher. 1998. Analysis of aliphatic biopolymers using thermochemolysis with tetramethylammonium hydroxide (TMAH) and gas chromatography-mass spectrometry. Org. Geochem. 29:1441-1451.

Dria, K.J., J.R. Sachleben, and P.G. Hatcher. 2002. Solid-state 13C NMR of humic acids at high magnetic field strengths. J. Environ. Qual. 31:393-401.

Gélinas, Y., J.A. Baldock, and J.I. Hedges. 2001. Demineralization of marine and freshwater sediments for CP/MAS 13C NMR analysis. Org. Geochem. 32:677-693.

Fabbri, D., G. Chiavari, and G.C. Galletti. 1996. Characterization of soil humin by Pyrolysis (methylation)—Gas Chromatography/Mass spectrometry; structural relationships with humic acids. J. Anal. Appl. Pyrol. 37:161-172.

Glaser, B., A. Dreyer, M. Bock, S. Fiedler, M. Mehring, and T. Heitmann. 2005. Source apportionment of organic pollutants of a highway-trafficinfluenced urban area in Bayreuth (Germany) using biomarker and stable carbon isotope signatures. Environ. Sci. Technol. 11:3911-3917.

González-Pérez, J.A., F.J. González-Vila, G. Almendros, and H. Knicker. 2004. The effect of fire on soil organic matter-A review. Environ. Int. 30:855-870.

González-Pérez, J.A., F.J. González-Vila, O. Polvillo, G. Almendros, H. Knicker, F. Salas, and J.C. Costa. 2002. Wildfire and black carbon in Andalusian Mediterranean forest. p. 1-7. In D.X. Viegas (ed.) Forest fire research and wildland fire safety [CD-ROM]. Millpress, Rotterdam, The Netherlands.

González-Vila, F.J., and G. Almendros. 2003. Thermal transformation of soil organic matter by natural fires and laboratory-controlled heatings. p. 153200. In R. Ikan (ed.) Natural and laboratory simulated thermal geochemical processes. Kluwer Academic Publishing, Dordrecht, The Netherlands.

González-Vila, F.J., A. Amblès, J.C. del Río, and L. Grasset. 2001b. 
Characterisation and differentiation of kerogens by pyrolytic and chemical degradation techniques. J. Anal. Appl. Pyrol. 58-59:315-328.

González-Vila, F.J., J.A. González-Pérez, O. Polvillo, G. Almendros, and H. Knicker 2002. Nature of refractory forms of organic carbon in soils affected by fires. Pyrolytic and spectroscopic approaches. In D.X. Viegas (ed.) Forest fire research and wildland fire safety. Millpress, Rotterdam, The Netherlands.

González-Vila, FJ., P. Tinoco, G. Almendros, and F. Martin. 2001. Pyrolysis-GCMS analysis of the formation and degradation stages of charred residues from lignocellulosic biomass. J. Agric. Food Chem. 49:1128-1131.

Hammes, K., R.J. Smernik, J.O. Skjemstad, A. Herzog, U.F. Vogt, and M.W.I. Schmidt. 2006. Synthesis and characterisation of laboratory-charred grass straw (Oryza sativa) and chestnut wood (Castanea sativa) as reference materials for black carbon quantification. Org. Geochem. 37:1629-1633.

Hatcher, P.G., and D.J. Clifford. 1994. Flash pyrolysis and in situ methylation of humic acids from soil. Org. Geochem. 21:1081-1092.

Heidenreich, R.D., W.M. Hess, and L.L. Bau. 1968. A test object and criteria for high resolution electron microscopy. J. Appl. Crystallogr. 1:1-19.

Herrera, M., G. Matuschek, and A. Kettrup. 2003. Fast identification of polymer additives by pyrolysis-gas chromatography/mass spectrometry. J. Anal. Appl. Pyrolysis. 70:35-42.

ISSS Working Group. 1998. World Reference Base for Soil Resources: Atlas. ISRIC-FAO-ISSS-Acco, Leuven.

Kawamoto, H., and S. Saka. 2006. Heterogeneity in cellulose pyrolysis indicated from the pyrolysis in sulfolane. J. Anal. Appl. Pyrol. 76:280-284.

Knicker, H., G. Almendros, F.J. González-Vila, F. Martín, and H.-D Lüdemann. 1996. ${ }^{13} \mathrm{C}$ - and ${ }^{15} \mathrm{~N}-\mathrm{NMR}$ spectroscopic examination of the transformation of organic nitrogen in plant biomass during thermal treatment. Soil Biol. Biochem. 28:1053-1060.

Knicker, H., F.J. Gonzalez-Vila, O. Polvillo, J.A. Gonzalez, and G. Almendros. 2005a. Fire-induced transformation of $\mathrm{C}$ - and $\mathrm{N}$-forms in different organic soil fractions from a Dystric Cambisol under a Mediterranean pine forest (Pinus pinaster). Soil Biol. Biochem. 37:701-718.

Knicker, H., K.U. Totsche, G. Almendros, and F.J. González-Vila. 2005b. Condensation degree of burnt peat and plant residues and the reliability of solid-state VACP MAS ${ }^{13} \mathrm{C}$ NMR spectra obtained from pyrogenic humic material. Org. Geochem. 36:1359-1377.

Kaloustian, J., A.M. Pauli, and J. Pastor. 2001. Kinetic study of the thermal decompositions of biopolymers extracted from various plants. J. Therm. Anal. Cal. 63:7-20.

Kuhlbusch, T.A.J. 1998. Black carbon and the carbon cycle. Science 280:1903-1904.

Lee, J.G., C.G. Lee, J.J. Kwag, A.J. Buglass, and G.H. Lee. 2005. Determination of optimum conditions for the analysis of volatile components in pine needles by double-shot pyrolysis-gas chromatography-mass spectrometry. J. Chromatogr. A. 1089:227-234.

Leifeld, J. 2007. Thermal stability of black carbon characterised by oxidative differential scanning calorimetry. Org. Geochem. 38:112-127.

Leinweber, P., H.-R. Schulten, and H. Jancke. 1999. New evidence for the molecular composition of soil organic matter in vertisols. Soil Sci. 164:857-870.

Lopez-Capel, E., S. Sohi, J.L. Gaunt, and D.A.C. Manning. 2005a. Use of Thermogravimetry-Differential Scanning Calorimetry to characterize modelable soil organic matter fractions. Soil Sci. Soc. Am. J. 69:136-140.

Lopez-Capel, E., R. Bol, and D.A.C. Manning. 2005b. Application of simultaneous thermal analysis mass spectrometry and stable carbon isotope analysis in a carbon sequestration study. Rapid Comm. Mass Spect. 19:3192-3198.

Lopez-Capel, E., G.D. Abbott, K.M. Thomas, and D.A.C. Manning. 2006a. Coupling of thermal analysis with quadrupole mass spectrometry and isotope ratio mass spectrometry for simultaneous determination of evolved gases and their carbon isotopic composition. J. Anal. Appl. Pyrol. 75:82-89.

Lopez-Capel, E., J.M. de la Rosa Arranz, F.J. Gonzalez-Vila, J.A. GonzalezPerez, and D.A.C. Manning. 2006b. Elucidation of different forms of organic carbon in marine sediments from the Atlantic coast of Spain using thermal analysis coupled to isotope ratio and quadrupole mass spectrometry. Org. Geochem. 37:1983-1994.

Lüdemann, H.-D., and H. Nimz. 1973. Carbon-13 nuclear magnetic resonance spectra of lignins. Biochem. and Biophys. Res. Comms. 52:1162-1169.

Manning, D.A.C., E. Lopez-Capel, and S. Barker. 2005. Seeing soil carbon: Use of thermal analysis in the characterization of soil C reservoirs of differing stability. Mineral. Mag. 6:425-435.

Martín, F., J.C. del Río, FJ. González-Vila, and T. Verdejo. 1995. Pyrolysis derivatization of humic substances 2. Pyrolysis of soil humic acids in the presence of tetramethylammonium hydroxide. J. Anal. Appl. Pyrol. 31:75-83.

Massiello, C.A. 2004. New directions in black carbon organic geochemistry. Mar. Chem. 92:201-213.

McKinney, D.E., J.M. Bortiatynski, D.M. Carson, D.J. Clifford, J.W. De Leeuw, and P.G. Hatcher. 1996. Tetramethylammonium hydroxide (TMAH) thermochemolysis of the aliphatic biopolymer cutan: Insights into the chemical structure. Org. Geochem. 24:641-650.

Moreno, J.M., and W.C. Oechel. 1995. The Role of Fire in Mediterraneantype Ecosystems, Springer, New York.

Plante, A.F., M. Pernes, and C. Chenu. 2005. Changes in clay associated organic matter quality in a $\mathrm{C}$ depletion sequence as measured by differential thermal analyses. Geoderma 129:186-199.

Pastorova, I., R.E. Botto, P.W. Arisz, and J.J. Boon. 1994. Cellulose char structure: A combined analytical Py-GC-MS, FTIR, and NMR study. Carbohydr. Res. 262:27-47.

Poirier, N., S. Derenne, J.N. Rouzaud, C. Largeau, A. Mariotti, and J. Balesdent. 2000. Chemical structure and sources of the macromolecular, resistant, organic fraction isolated from a forest soil (Lacadeé, South West France). Org. Geochem. 31:813-827.

Poirier, N., S. Derenne, J. Balesdent, J.N. Rouzaud, A. Mariotti, and C. Largeau. 2002. Abundance and composition of the refractory organic fraction of an ancient, tropical soil (Pointe Noire, Congo). Org. Geochem. 33:383-391.

Quénéa, K., S. Derenne, C. Largeau, C. Rumpel, and A. Mariotti. 2005. Spectroscopic and pyrolytic features and abundance of the macromolecular refractory fraction in a sandy acid forest soil (Landes de Gascogne, France). Org. Geochem. 36:349-362.

Rumpel,C.,H.Knicker,I.Kögel-Knabner,J.O.Skjemstad,andR.F.Hüttl.1998.Types and chemical composition of organic matter in reforested lignite-rich minesoils Geoderma 86:123-142.

Schmidt, M.W.I., H. Knicker, P.G. Hatcher, and I. Kögel-Knabner. 1997. Improvement of 13C and 15N CPMAS NMR spectra of bulk soils, particle size fractions and organic material by treatment with $10 \%$ hydrofluoric acid. Eur. J. Soil Sci. 48:319-328.

Schmidt, M.W.I., and A. Noack. 2000. Black carbon in soils and sediments: Analysis, distribution, implications, and current challenges. Glob. Biogeochem. Cycles 14:777-793.

Schmidt, M.W.I., J.O. Skjemstad, C.I. Czimczic, B. Glaser, K.M. Prentice, Y. Gelinas, and T.A.J. Kuhlbusch. 2001. Comparative analysis of black carbon in soils. Global Biol. Cycles 15:163-167.

Sebag, D., J.R. Disnar, B. Guillet, C. Di Giovanni, E.P. Verrecchia, and A. Durand. 2006. Monitoring organic matter dynamics in soil profiles by 'Rock-Eval pyrolysis': Bulk characterisation and quantification of degradation. Eur. J. Soil Sci. 57:344-355.

Siewert, C. 2004. Rapid screening of soil properties using thermogravimetry. Soil Sci. Soc. Am. J. 68:1656-1661.

Simpson, M.J., B. Chefetz, A.P. Deshmukh, and P.G. Hatcher. 2005. Comparison of polycyclic aromatic hydrocarbon distributions and sedimentary organic matter characteristics in contaminated, coastal sediments from Pensacola Bay, Florida. Mar. Environ. Res. 59:139-163.

Smith, B.N., and S. Epstein. 1971. Two categories of 13C/12C ratios for higher plants. Plant Physiol. 47:380-384.

Suman, D.O., T.A.J. Kuhlbusch, and B. Lim. 1997. Marine sediments: A reservoir for black carbon and their use as spatial and temporal records of combustion. p. 71-293. In J.S. Clark, et al. (ed.) Sediment Records of Biomass Burning and Global Change. NATO ASI Series I: Glob. Env. Change 51. Springer-Verlag, Berlin, Heidelberg. Germany.

Wilson, M.A. 1987. NMR Techniques and Applications in Geochemistry and Soil Chemistry. Pergamon Press, Oxford.

Yoshioka, H., and R. Ishiwatari. 2002. Characterization of organic matter generated from Green River shale by infrared laser pyrolysis. Geochem. J. 36:73-82. 